\title{
DIRECT IDENTIFICATION OF CRIME BY INQUIRY AGENCY IN THE PROCESS OF OPERATIONAL-SEARCH ACTIVITIES
}

\section{Sachko O. V.}

\section{INTRODUCTION}

Information throughout human history has been and remains the driving force of history itself, and, progress, is an important factor in the activity of detecting and investigating crimes, operational investigative measures and the criminal process as a whole.

For millennia, no state could do without truthful information information about events, phenomena, facts, or about individuals. The means and forms of obtaining such information have become more sophisticated and diverse, and subsequently increasingly filigree, including unspoken intelligence methods.

Since the emergence of a former fugitive in the field of police, the French convict Eugene François Vidock (1811), who was able to bring the whistleblowing and tracking to the rank of science and art at the same time and received the title of «emperor of detectives», content, methods and forms of operational and search activities have changed a lot. On the one hand, electronic tracking and various operational and technical means are increasingly used. On the other hand, investigative activities are increasingly under the control of the law and the state. There has been a tendency for more extensive use of the results of investigative activities directly in the prosecution of criminal cases ${ }^{1}$.

As D. Bedniakov rightly points out, criminal activity, which is carefully prepared and conspired, must be confronted with a set of

Тертишник В.М. Гарантії прав i свобод людини та забезпечення встановлення істини в кримінальному процесі України: дис. на здобуття наук. ступеня доктора юрид. наук: спец. 12.00 .09 «кримінальний процес, та криміналістика; судова експертиза; оперативно-розшукова діяльність» / В. М. Тертишник. - Дніпропетровск, 2009. - С. 222. 
operational search (mostly silent, search) measures and investigative actions, without which it is impossible to ensure the inevitability of the responsibility of criminals.

Operational search activity is a system of public and private search, intelligence and counterintelligence, preventive measures carried out by the bodies of inquiry - subjects of operational and search jurisdiction in accordance with the law and other normative acts, using operative and operational-technical methods and means aimed at solving the problem of finding and recording the actual data on the intelligence and subversive activities and unlawful activities of individuals and groups in order to identify, suspension, disclosure, prevention and prevention of crimes, as well as in the interests of criminal justice and information in the interests of the security of society and the state ${ }^{2}$.

Operational-search information is any information received by the operational-search units or specific operational staff in accordance with their competence from any sources and in the form provided by the departmental legal acts, as well as the summary data of these units or specific operational employees, having operational and investigative value ${ }^{3}$.

Gutsulyak Y. views operational and search information as confidential factual data about persons, phenomena and processes, objects and documents, facts, events that are lawfully obtained, are obtained during the implementation of the ARD and are of interest to the judiciary. Operational-search information, taking into account the specifics of the ARD, by fixing in a certain way on the material media with the appropriate details that allow them to identify, goes into the concept of the document, after which it concentrates on information systems and matters of operational accounting ${ }^{4}$.

2 Бедняков Д.И. Непроцессуальная информация и расследование преступлений / Д.И. Бедняков. - М.: Юрид. лит. 1991. - С. 17.

3 Тертишник В. М. Верховенство права та забезпечення встановлення істини в кримінальному процесі України: Монографія / В.М. Тертишник. Дніпропетровськ: Дніпроп. держ. ун-т внутр. Справ; Ліра ЛТД, 2009. - С. 192.

4 Погорецкий Н.А. Использование результатов ОРД в качестве доказательств в уголовном процессе России и Украины: сравнительный анализ / Н. А. Погорецкий // Российский следователь. - 2003. - № 4. С. 45-47. 
The content of the operative-search information is the information contained in it about the prepared, conceived, commenced or committed crime and persons involved in it, it is information about the ways of committing crimes; signs of criminals, stolen items; the circumstances relevant to the planning and implementation of the crime detection and disclosure measures and to the facilitation of the pre-trial investigation. The value of such information is that it provides an opportunity to identify and discover facts of unobtrusive, latent, hidden crimes, to obtain information about specific persons involved in them, who are usually masked, concealed, conspired and prevented from receiving information about them. The method of obtaining operational information is mostly unspoken, reconnaissance, carried out with the help of special forces, means and methods of operative-search activity, which are carried out secretly by persons interested in counteracting the truth, which allows to obtain the necessary data quickly and effectively ${ }^{5}$.

From the analysis of the legislation and the scientific works concerning the operative-search activity and the provisions of the criminal process, related to it, it can be stated that the operativesearch activity is a certain system of actions, combined with a common purpose and task, which emerge as an operative-search relationship. but mostly in the interests of the judiciary. Accordingly, operative-investigative activity as an operative-investigative process, having the form of a legal relationship, provided the appearance of facts that indicate the signs of a crime, can turn into a legal criminal procedure.

According to Art. 1 of the Law of Ukraine «On Operational Investigation Activities» the task of the operational investigative activity is to search and record the actual data on the illegal actions of individuals and groups, the responsibility for which is provided by the Criminal Code of Ukraine ${ }^{6}$, intelligence and subversive activity of

5 Гуцуляк Ю. Оперативно-розшукова діяльність та оперативно розшуковий процес: взаємозв'язок та співвідношення. / Ю. Гуцуляк // Підприємництво, господарство і право. - № 10. - 2002. - С. 107-110.

Гуцуляк Ю. Оперативно-розшукова діяльність та оперативно розшуковий процес: взаємозв'язок та співвідношення. / Ю. Гуцуляк // Підприємництво, господарство і право. - № 10. - 2002. - С. 107-110. 
special services of foreign states and organizations for the purpose of termination offenses and in the interests of criminal justice, as well as information in the interests of the security of citizens, society and the state.

\section{Operational search information and subjects of its receipt}

If the classification is based on the principle of correlation of the goals of the operational search activities, other authors write, then there are three types of information:

Information of universal importance: for predicting individual behavior, prevention and disclosure of crimes. This type of information is formed around the factors that affect the operational environment and the personality characteristics of those who, in a certain coincidence, may commit crimes (persons of operational interest). It occurs in connection with criminogenic social phenomena, but along with them reflects objective phenomena that remain neutral for the ARD (eg, description of appearance, hobbies, interests. Circle of communication of the investigated persons).

Criminal justice information is a process of proof. It is generated by the circumstances of the crime and the subsequent actions of the criminals, their accomplices and others. Its content is factual evidence that indicates the event of the crime, the actions of the offender, the circumstances that aggravate or mitigate their guilt, and other categories covered by the subject of evidence. If the purpose of the first type of information regarding the disclosure of crimes is to determine in advance the range of persons who may be criminals, then the purpose of the second type of information is to ensure the identification of persons who have committed or commit specific crimes, to obtain evidence of their guilt. The second class should also include information that enables the search of persons evading the investigation, the court and those who have escaped from custody.

Information, the purpose of which is determined by the needs of operational-search tactics. This type of information provides information about the general operational situation (operationaltactical situation), which should be taken into account when choosing forms and techniques of operational-tactical actions. The characteristics of the persons being inspected, the account of the tactical capabilities of the subsidiary apparatus, the features of 
counter-measures taken by interested persons, and a number of other factors are taken into account ${ }^{7}$.

Procedural science faces a very important and difficult task of covering operational activities with well-defined legal frameworks and creating a control procedure.

Nowadays, with the transition from regulation of operativeinvestigative activity by departmental by-laws to its legislative regulation, both conceptual views on the operative-investigative activity and on its place in the sphere of criminal justice have been changed, research has been carried out on the methods of operativeinvestigative activity itself as well as its forensic and evidentiary aspects $^{8}$.

Meanwhile, the problem of using LDA results as reasons and reasons for making information in the LDR has not been investigated yet. Operational-search activity under the current legislation is carried out by operational units: 1) National Police - units of criminal and special police; 2 ) the State Bureau of Investigation - internal security, personal security; 3) Security services of Ukraine - counterintelligence, military counterintelligence, protection of national statehood, special units on fight against corruption and organized crime, operational-technical, internal security, operative documentation, fight against terrorism and protection of participants of criminal justice and employees of criminal proceedings and employees; 4) Foreign Intelligence Services of Ukraine - intelligence intelligence, operational and technical, own security; 5) State Border Service of Ukraine - intelligence agency of specially authorized central executive body for state border protection (agent intelligence, operational and technical security, own security), operative-search units according to specially authorized central executive body of state security and territorial bodies, units for protection of the state border of bodies of state border protection and Maritime security, provision of internal security team, ensuring their own security, operational

${ }^{7}$ Горяинов К.К. Оперативно-розыскная деятельность: Учебник. 2-е изд. / К.К. Горяинов, В.С. Овчинский, Г.К. Синилов, А.Ю. Шумилов. - М.: Инфра M, 2004. -848 c.

Бедняков Д.И. Непроцессуальная информация и расследование преступлений / Д.И. Бедняков. - М.: Юрид. лит. 1991. - 208 с. 
documentation and operational and technical; 6) State Security Directorate - a unit of operational security for the sole purpose of ensuring the safety of persons and objects subject to state protection; 7) bodies of revenue and fees - operational units of the tax police and units that fight smuggling; 8) bodies and institutions of execution of penalties and remand prisons of the State Penal Enforcement Service of Ukraine; 9) Intelligence body of the Ministry of Defense of Ukraine - operational, operational-technical, own security; 10) the National Anti-Corruption Bureau of Ukraine - detectives, operational and technical, internal control ${ }^{9}$.

The carrying out of operative-search activities by other divisions of these bodies, divisions of other ministries, departments, public, private organizations and persons is prohibited.

According to Art. 8 of the Law of Ukraine «On Operational Investigation Activities» the operational units are entitled to ${ }^{10}$ :

1) to interview persons with their consent, to use their voluntary assistance;

2) to carry out controlled delivery and controlled and prompt purchase of goods, objects and substances, including those forbidden for circulation, from individuals and legal entities regardless of the form of ownership in order to identify and document the facts of illegal acts. Carrying out controlled delivery, controlled and operational procurement is carried out in accordance with the provisions of Article 271 of the Criminal Procedure Code of Ukraine in accordance with the procedure established by the normative legal acts of the Ministry of Internal Affairs of Ukraine, the central body of executive power, which ensures the formation and implementation of state tax and customs security, agreed with the Prosecutor General's

9 Адашкевич Ю.Н. Агентурный метод в борьбе с преступностью в зарубежных странах. Организованная преступность / под ред. А.И. Долговой, С.В. Дьякова. - М., 1999. - С. 212-213;

10 Закон України «Про оперативно-розшукову діяльність» від 18 лютого 1992 р. // Відомості Верховної Ради України. - 1992. - № 22. - Ст. 303; зі змінами відповідно до Законів № 5463-VI (5463-17) від 16.10.2012; N 1798-VIII ( 1798-19 ) від 21.12.2016, ВBP, 2017, N 7-8, ст.50; N 1965-VIII (1965-19 ) від 21.03.2017, ВBP, 2017, N 16, ст.199; N 2505-VIII ( 2505-19) від 12.07.2018 \} URL: http://zakon.rada.gov.ua/laws/show/2135-12 
Office of Ukraine and registered with the Ministry of Justice of Ukraine;

3 ) raise the issue of inspections of financial and economic activity of enterprises, institutions, organizations irrespective of the form of ownership and persons engaged in entrepreneurial activity or other types of economic activity individually, and participate in their conduct;

4) to get acquainted with the documents and data characterizing the activity of enterprises, institutions and organizations, to study them, at the expense of the funds allocated for the maintenance of the units carrying out operational search activities, to make copies of such documents, at the request of heads of enterprises, institutions and organizations - exclusively in the territory of such enterprises, institutions and organizations, and with the permission of the investigating judge in the order prescribed by the Criminal Procedure Code of Ukraine, require documents and data that characterize the activities of enterprises, institutions, organizations, as well as the way of life of individuals suspected of committing or committing a crime, the source and size of their income, leaving copies of such documents and describing the seized documents to the persons in which they are claimed and ensuring their preservation and return in due course. The removal of the originals of the primary financial and economic documents is prohibited except in cases provided for by the Criminal Procedure Code of Ukraine;

5) carry out operations on the capture of criminals, termination of crimes, intelligence and subversive activity of special services of foreign states, organizations and individuals;

6 ) visit dwellings and other premises with the consent of their owners or residents to find out the circumstances of the crime being committed, as well as collect information about the illegal activities of the persons under investigation;

7) identify and record the traces of grave or particularly grave crime, documents and other objects that may be evidence of preparation or commission of such crime, or receive intelligence, including through the penetration and examination of publicly inaccessible places, housing or other possession of a person according to with the provisions of Article 267 of the Criminal Procedure Code of Ukraine; 
7-1) in order to identify and record the actions provided for in Articles 305, 307, 309, 311, 318, 321, 364-1, 365-2, 368, 368-3, 368-4, 369, 369-2 of the Criminal Code Ukraine (2341-14), conduct operations on the controlled commission of appropriate actions. The procedure for obtaining a permit, its period of validity and the procedure for conducting an operation for controlled commission of corruption are determined by the Criminal Procedure Code of Ukraine);

8) perform a special task of disclosing the criminal activity of an organized group or criminal organization in accordance with the provisions of Article 272 of the Criminal Procedure Code of Ukraine (4651-17);

9) carry out audio, video control of a person, removal of information from transport telecommunication networks, electronic information networks in accordance with the provisions of Articles 260, 263-265 of the Criminal Procedure Code of Ukraine (4651-17);

10) seize correspondence, review and seize it in accordance with the provisions of Articles 261, 262 of the Criminal Procedure Code of Ukraine;

11) to observe the person, thing or place, as well as audio-video control of the place in accordance with the provisions of Articles 269, 270 of the Criminal Procedure Code of Ukraine (4651-17);

12) to establish the location of the radio-electronic device in accordance with the provisions of Article 268 of the Criminal Procedure Code of Ukraine (4651-17);

13) have vowel and mute staff and freelance employees;

14) use confidential cooperation in accordance with the provisions of Article 275 of the Criminal Procedure Code of Ukraine (4651-17);

$15)$ to receive information from legal or natural persons, free of charge or remuneration, about crimes committed or committed and about the threat to the security of society and the state;

16) use with the consent of the administration office premises, vehicles and other property of enterprises, institutions, organizations, as well as with the consent of persons - housing, other premises, vehicles and property belonging to them;

17) create and use pre-identified (marked) or false (imitation) means in accordance with the provisions of Article 273 of the Criminal Procedure Code of Ukraine; 
18) create and apply automated information systems;

19) to apply the means of physical influence, special means and firearms on the grounds and in accordance with the procedure established by the laws on the National Police (580-19), the Security Service of Ukraine (2229-12), the State Border Guard Service of Ukraine (661-15), the State Guard of state bodies of Ukraine and officials (160/98-BP), Customs Code of Ukraine (4495-17);

20) to address, within the limits of its authority, requests to law enforcement agencies of other states and international law enforcement organizations in accordance with the legislation of Ukraine, international treaties of Ukraine, as well as the constituent acts and rules of international law enforcement organizations of which Ukraine is a member (Article 8 of the Law of Ukraine "On Operational - search activity).

In the course of these actions, signs of a crime can be directly identified and a variety of pieces of evidence can be obtained (videotapes with a record of the actions of criminals, photocopies, weapons, drugs, recording materials, filming, etc.).

\section{Legislative regulation of the use of operational and search tools}

The problem is the legal certainty of the envisaged operativeinvestigative measures and unspoken investigative (investigative) actions, their competition is not ruled out, the imperfection of the blanket way of regulating certain actions, other defects of the legislation that often make it impossible to apply them. For example, the requirements of claim 2) Part 1 of Art. 8 of the ARD Law that "controlled delivery, controlled and operational procurement shall be carried out in accordance with the provisions of Article 271 of the Criminal Procedure Code of Ukraine in accordance with the procedure established by the normative acts of the Ministry of Internal Affairs of Ukraine, the central executive body that ensures the formation and implementation state tax and customs policy, the Security Services of Ukraine, agreed with the Prosecutor General's Office of Ukraine and registered with the Ministry of Justice of Ukraine «is not consistent with norms of the CPC of Ukraine. The CPC of Ukraine has only indicated the possibility of applying this measure, but there are still no provisions governing its implementation. Moreover, such a procedure cannot be regulated by 
the departmental regulations. After all, according to Part 5. Art. 371 of the CPC of Ukraine, «the procedure and tactics of carrying out controlled delivery, controlled and operational procurement, special investigative experiment, simulating the crime situation is determined by law» and not by departmental instructions.

Regarding the legal certainty of the means of obtaining evidential information, here we have a unique message when the legislator, who would have to do it, adopting the CPC of Ukraine as a complex legislative act, did not do so, postponing this work to virtual other laws of the future, and more Moreover, «it has encroached on the fact that even the tactics of such actions (which are usually selected depending on the investigative situation on the condition of confidentiality) are now also regulated by law.» What is tactics and how to regulate it the legislator «kept silent».

Moreover, according to Art. 86 of the CPC of Ukraine «Evidence is admissible if it is received in accordance with the procedure established by this Code» ${ }^{11}$.

According to Part 3 of Art. 271 of the CPC of Ukraine «during the preparation and conduct of crime control measures, it is forbidden to provoke (incite) a person to commit this crime for the purpose of further exposing it, helping the person to commit a crime that he would not have committed if the investigator had not facilitated it or with for the same purpose to influence her behavior by violence, threats, blackmail. Items and documents obtained in this way cannot be used in criminal proceedings. "

The Law of Ukraine «On Measures to Combat the Illicit Trafficking of Drugs, Psychotropic Substances, Precursors and Their Abuse» provides for such operational-search measures as controlled delivery and purchase. In Art. 5 of this Law provides that "for obtaining evidence of criminal activity related to illicit trafficking in narcotic drugs, psychotropic substances and precursors, employees of

11 Тертишник В. М., Сачко О. В., Уваров В.Г. Контроль за вчиненням злочину: зміст, форма та юридична визначеність. Актуальні проблеми вітчизняної юриспруденції. - 2016. - № 4. - С. 132-135. Корнієнко М. В. Доктринальні проблеми інституту негласних слідчих (розшукових) дій / М. В. Корнієнко, В. М. Тертишник // Международный научный журнал «Верховенство права». - 2016. - № 4. - С. 62-68. 
bodies (subdivisions) who have been granted the right to carry out operative-search activity, according to the resolution of the head of the relevant body, agreed the prosecutor, is allowed to carry out an operation for the purchase of narcotic drugs, psychotropic substances or precursors - prompt purchase. The procedure for conducting an operational purchase is determined by a normative act of the Ministry of Internal Affairs of Ukraine, the Security Service of Ukraine, agreed with the Prosecutor General's Office of Ukraine and the Ministry of Justice of Ukraine.

Here, the same methodological error of the application of the blanket method, due to the unsuccessful attempts to regulate the operative measures by departmental instructions, which calls into question their legal certainty, compliance with the requirements of Art. 19 of the Constitution of Ukraine, and a clear interpretation of the possibilities of using the results of such actions in evidence.

With the help of operative-search measures the receipt and verification of primary information on the signs of criminal activity of specific persons and groups, on the committed crimes and persons involved in it are ensured; identification of persons aware of crimes, detection of property, money and values obtained by crime, objects, documents and other objects - bearers of evidential information, their preservation; identification of criminals, whereabouts of persons hiding from the bodies of inquiry, investigation and court.

Operational-search information can testify to the preparation of a latent crime, an attempt on a crime, the commission of a latent crime, the phenomena that indicate the continued criminal activity of specific persons, and reveals not only the mechanism of crimes, but also the mechanism of occurrence of traces of such crimes, and thereby possibility of their investigation and disclosure of crime.

It may also be information that constitutes, first, information relating to the formation of the offender's personality, as well as information about the relevant situations in which the offender may be committing the crime; secondly, information about personal qualities and habits is subjectively inherent to that person, which often plays an important role in the commission of a particular crime, as well as the characteristics of a person who has a tendency to commit a criminal act that is within the scope of law enforcement agencies. 
According to Zazytskyi V.I., in the context of the provisions of the Law on ARD, "the results of the operative-search activity should be considered the data (reports, information) obtained during the implementation of the operative-search activities, as well as from the confidants and recorded in the materials of the cases of operational accounting. These summaries should reflect the circumstances of the crime and other circumstances relevant to the speedy and full disclosure of the crime by criminal proceedings». ${ }^{12}$

Such results of the ARD can be used both to detect and prevent a criminal offense, as well as to detain a person directly at the scene of a criminal offense or to detect criminal activity.

For the development of technology for direct detection of crimes by operational investigative measures, today there is an acute problem of improving the legal form of the operational investigative activity itself. Recall that according to Art. 19 of the Constitution of Ukraine «state bodies and bodies of local self-government, their officials are obliged to act only on the basis, within the powers and in the manner provided by the Constitution and laws of Ukraine».

Operational-search activities should be codified and regulated in detail in the Law of Ukraine "On Operational-Investigation Activities". Meanwhile, with the adoption of the CCP in 2012, the tendency to process the methods of ARDs and to create an institute of so-called "secret investigative actions" has revived. Article 263 of the CPC of Ukraine regulates "Removal of information from transport telecommunication networks", Article 264 "Removal of information from electronic information systems", Article 267 "Surveying of publicly inaccessible places, dwelling or other possession of a person", Article 269 "Observation of a person, thing or place".

In Art. 260 of the CCP is defined as follows: "Audio, video control of a person is a form of interference with private communication, which is carried out without its knowledge on the basis of the order of the investigating judge, if there are sufficient reasons to believe that the person's conversations or other sounds,

12 Комментарий к Федеральному закону «Об оперативно-розыскной деятельности» / Отв. ред. А.Ю. Шумилов. - М., 1997. - С.109. Похожее определение результатам ОРД дают В.М. Мешков, В.Л. Попов. См.: Указ. работа. - М., 1999. - С. 45. 
movements, actions related to its activities or location, etc., may contain information relevant to the pre-trial investigation».

Article 270 of the Code of Criminal Procedure of Ukraine "Audio, video control of a place" states the following: "Audio, video control of a place can be carried out during the pre-trial investigation of a serious or especially grave crime and consists in carrying out the concealed fixing of information by means of audio, video recording inside publicly accessible places without the knowledge of their owner, owner or persons present in the place, if there is information that the conversations and behavior of the persons in this place, as well as other events occurring there, may contain information that is meaningful I am for criminal proceedings".

In the scientific literature, interesting suggestions have already been made and substantiated in this regard. Thus, V.M. Tertyshnik rightly proposes to supplement the system of investigative actions with a new procedural form of obtaining evidence «Direct observation»:

"In order to establish the circumstances of the event of the crime, as well as other facts relevant to the case, the investigating body shall, on its own initiative or on behalf of the investigator, on its own initiative or on behalf of the investigator, directly monitor certain events, facts or actions of individuals. direct observation and technical documentation of the facts investigated.

The tasks of direct observation are: detection and disclosure of a crime, study and technical documentation of the circumstances of its commission, fixing traces and other factual data, obtaining the necessary information and providing the conditions for successful precautionary measures and detention of the suspect on the spot.

This investigative action is carried out by visual observation of the actions of the suspects in the preparation, preparation or commission of the crime of persons or by the individual circumstances of the event of the crime, as well as technical documentation of such facts.

Surveillance may be carried out in any place other than the dwelling of citizens and other private property, as well as the territory of enterprises, institutions and organizations and other objects, if it may entail the disclosure of information of a secret nature.

By way of exception, with the consent of the residents of the living quarters and the reasoned decision of the investigator or the 
body of inquiry on the sanction of the prosecutor, direct observation and technical documentation of the investigated facts may be carried out in the living quarters. Without the consent of the residents of the premises, direct observation in it is not allowed.

With the consent of the owner of the private possession and the reasoned decision of the investigator or the body of inquiry on the sanction of the prosecutor, direct observation and technical documentation of the investigated facts can be carried out in such private possession. Without the consent of the owner of the private possession, direct observation in it is not allowed.

With the consent of the persons occupying the official premises or the reasoned decision of the investigator or the body of inquiry with the sanction of the prosecutor, the direct observation and technical documentation of the investigated facts may be carried out in the official or other premises which is not the private possession of the person.

Where necessary, the inquiry body may invite members of the public to participate in the observation and involve the necessary experts. In the course of the surveillance, the investigating body examines and records the circumstances of the crime and the suspected persons, identifies and attaches traces of the crime and other factual data, uses photography, filming, sound and video, uses optical and other necessary technical means.

Participants in the direct observation shall be warned of the use of the technical means and informed of the results of their use. Appropriate methods shall be used to certify the actual results of the technical documentation.

The protocol on the implementation of direct observation and technical documentation is made in compliance with the requirements of the CPC of Ukraine. The protocol describes everything found in the form in which it was observed, and all the actions in the sequence in which they occurred, as well as in compliance with the requirements of Art. CPC of Ukraine, displays information about the procedure and results of the use of technical means. The results of the technical documentation have the value of an independent type of evidence and are stored in the case.

Persons involved in the surveillance as eyewitnesses to a crime or an investigated event may not be involved in further investigation and 
are subject to removal, but may be questioned as witnesses. The protocol of direct observation, together with the actual results of the actual documentation, shall be immediately transmitted to the investigator, and if the observation was made prior to the commencement of the preliminary investigation, may lead to the opening of criminal proceedings and be subject to registration together with the appearance of the duty and other allegations and reports of crimes.

The investigator and the investigating authority are obliged to take measures to exclude the possibility of disclosure of secret information or intimate and other data concerning the personal life, honor and dignity of the person obtained in the process of observation, if they do not contain information about the crime. ${ }^{13}$

Based on the practice of regulating the removal of information from technical channels of communication, both as an investigative action and an operational search measure, as well as the tendency to process the means of ARD and regulate them in the CPC of Ukraine as so-called vague investigative (search) actions, we assume that at this stage it is advisable in the same way to regulate in the above order direct observation and technical documentation as a universal complex nature of the investigative action.

Implementation of operational materials can be carried out by both investigator and operative. However, in all cases, the opening of criminal proceedings should be preceded by joint consideration. In this case, the materials of direct detection by the body of inquiry of the crime, for example, the materials about detected theft, as a rule, are jointly discussed by the investigator and the operative. The investigator has the right to return such materials to the inquiry authority for further examination. In this case, it draws up a written opinion, indicating the circumstances that hinder the opening of the proceedings, as well as the measures to be taken to eliminate the gaps.

13 Тертишник В.М. Кримінально-процесуальне право України. Подручник. 5-те вид. доп. і перероб. / В.М. Тертишник - Київ: А. С. К., 2007. С. 617-623; Тертышник В.М. Непосредственное наблюдение: модель нового следственного действия / В.М. Тертышник // Именем Закона. - Киев, 1993. № 8. - С. 5-6. 


\section{CONCLUSIONS}

The use of ARD results as an excuse and reason for opening criminal proceedings: the problem of implementing this direction has never been as acute as the issue of proving the use of investigative information. Indirectly, this is confirmed by the topic of scientific discussions ${ }^{14}$.

Many scientists have occupied and occupy a position according to which operative-search information may well be realized through the system of motives present in the current criminal procedural law. In particular, on the grounds that it is the direct detection of the crime by a body of inquiry. However, allowing such a realization, they do not deny (and some emphasize) that there is an objective need to separate the results of the ARD into a separate reason for opening criminal proceedings ${ }^{15}$.

Article 10 of the Law of Ukraine "On Operational Investigation Activities" states: "The materials of the Operational Investigation Activity shall be used: 1) as a pretext and basis for initiating a pretrial investigation; 2) to obtain factual data which may be evidence in criminal proceedings; 3) for the prevention, detection, termination and investigation of crimes, reconnaissance attacks against Ukraine, the search for criminals and persons who have disappeared".

One of the questions that is being resolved today by jurists is whether the LDA Law's statement that the LDA results can be a reason and ground for opening criminal proceedings are legitimate (in terms of criminal procedure law) ${ }^{16}$. According to Kalnitsky V.V. and Nikolaev Yu.A., the specified norm is criminal procedure and should not be placed in the Law on ARD. According to them, the provisions of the said law are declarative and serve only to correct the practitioners' legal consciousness.

14 Григорьев В.Н. Обнаружение признаков преступления органами внутренних дел / В.Н. Григорьев. - Ташкент, 1986. - С. 56-59.

${ }^{15}$ Попов А.П. Непосредственное обнаружение признаков преступления как повод к возбуждению уголовного дела. - Автореф. дис. ... канд. юрид. наук / А.П. Попов. - Н. Новгород, 1999. - 19 с.

16 Кальницкий В.В. Возбуждение уголовного дела в системе уголовнопроцессуальной и оперативно-розыскной деятельности / В.В Кальницкий, Ю.А. Николаев // Вопросы применения Федерального закона «Об оперативнорозыскной деятельности». - Омск:, 1998. - С. 29. 
In the same vein, Zemskaya A.V. thinks: not recognizing the investigative formulation of the Law on ARDs with criminal procedural directivity, she notes that the rule stated in the operativesearch law only «serves as a guideline for operative workers, targets them, that they see the prospect of selling the materials they have prepared as legal facts that give rise to criminal proceedings»». ${ }^{17}$

In the literature there were also sharply critical comments about the fact that «the results of the ARD can be the reason and the reason ...». Gromov N.A., Gushchin A.N., Frantsiferov Y.V. noticed: «... the same array of information cannot simultaneously be the cause (that is, the reason), and the consequence (that is, the reason) of the occurrence of a certain phenomenon (in our case, the initiation of a case).» And further, "securing in law other than the CCP the law of additional reason to open criminal proceedings is hardly expedient, since the data obtained as a result of operative-investigative activity in their use as an excuse require procedural interpretation ${ }^{18}$.

Another problem is seen here, which has a direct bearing on the specificity of the results of the ARD as reasons and grounds for opening criminal proceedings. Conditionally, it can be called a problem of delaying the implementation of the principle of publicity. Although, probably, it is more correct to speak not about the postponement, but about the specifics of implementation of the said principle in certain categories of criminal proceedings.

\section{SUMMARY}

The investigative activity is an instrument of providing evidence in criminal proceedings. The role of operative-search information is explained in the paper, the ways of its reception are listed. The role of methods used in the process of operational and search activities is investigated. An important place is occupied with the study of information-criminal and evidential aspects. The subjects of carrying

17 Земскова А.В. Правовые проблемы использования результатов оперативно - розыскных мероприятий в уголовно-процессуальном доказывании / А.В. Земскова. - Волгоград, 2000. - С. 62-63.

18 Гущин А.Н. Использование оперативно - розыскной информации в уголовно-процессуальном доказывании / А.Н. Гущин, Ю.В. Франциферов , Н.А. Громов // Российский следователь. - 2000. - № 4. - С. 15. 
out the search activity of their tasks and responsibilities are described. Means of obtaining evidential information and expediency of codification and regulation of operative-search measures are investigated.

\section{REFERENCES}

1. Тертишник В.M. Гарантії прав і свобод людини та забезпечення встановлення істини в кримінальному процесі України: дис. на здобуття наук. ступеня доктора юрид. наук: спец. 12.00.09 «кримінальний процес, та криміналістика; судова експертиза; оперативно-розшукова діяльність» / В. М. Тертишник. - Дніпропетровск, 2009. - 473 с.

2. Бедняков Д.И. Непроцессуальная информация и расследование преступлений / Д.И. Бедняков. - М.: Юрид. лит. 1991. - $208 \mathrm{c}$.

3. Тертишник В. М. Верховенство права та забезпечення встановлення істини в кримінальному процесі України: Монографія / В.М. Тертишник. - Дніпропетровськ: Дніпроп. держ. ун-т внутр. Справ; Ліра ЛТД, 2009. - 404 с.

4. Погорецкий Н.А. Использование результатов ОРД в качестве доказательств в уголовном процессе России и Украины: сравнительный анализ / Н. А. Погорецкий // Российский следователь. - 2003. - № 4. С. 45-47.

5. Гуцуляк Ю. Оперативно-розшукова діяльність та оперативно - розшуковий процес: взаємозв'язок та співвідношення. / Ю. Гуцуляк // Підприємництво, господарство і право. - № 10. - 2002. - С. 107-110.

6. Горяинов К.К. Оперативно-розыскная деятельность: Учебник. 2-е изд. / К.К. Горяинов, В.С. Овчинский, Г.К. Синилов, А.Ю. Шумилов. - М.: Инфра - М, 2004. - 848 с.

7. Адашкевич Ю.Н. Агентурный метод в борьбе с преступностью в зарубежных странах. Организованная преступность / под ред. А.И. Долговой, С.В. Дьякова. - М., 1999. - С. 212-213;

8. Закон України «Про оперативно-розшукову діяльність» від 18 лютого 1992 р. // Відомості Верховної Ради України. - 1992. № 22. - Ст. 303; зі змінами відповідно до Законів № 5463-VI (5463-17) від 16.10.2012; - N 1798-VIII ( 1798-19) від 21.12.2016, 
BВP, 2017, N 7-8, ст.50; N 1965-VIII ( 1965-19 ) від 21.03.2017, BBP, 2017, N 16, ст.199; N 2505-VIII ( 2505-19 ) від 12.07.2018\} URL: http://zakon.rada.gov.ua/laws/show/2135-12.

9. Тертишник В. М., Сачко О. В., Уваров В.Г. Контроль за вчиненням злочину: зміст, форма та юридична визначеність. Актуальні проблеми вітчизняної юриспруденції. - 2016. - № 4. C. 132-135.

10.Корнієнко М. В. Доктринальні проблеми інституту негласних слідчих (розшукових) дій / М. В. Корнієнко, В. М. Тертишник // Международный научный журнал «Верховенство права». - 2016. - № 4. - С. 62-68.

11.Комментарий к Федеральному закону «Об оперативнорозыскной деятельности» / Отв. ред. А.Ю. Шумилов. - М., 1997. - C. 109.

12.Похожее определение результатам ОРД дают В.М. Мешков, В.Л. Попов. См.: Указ. работа. - М., 1999. - 444 с.

13.Тертишник B.M. Кримінально-процесуальне право України. - Подручник. 5-те вид. доп. i перероб. / В.М. Тертишник - Київ: А. С. К., 2007. - 848 с.

14.Тертышник В.М. Непосредственное наблюдение: модель нового следственного действия / В.М. Тертышник // Именем Закона. - Киев, 1993. - № 8. - С. 5-6.

15.Григорьев В.Н. Обнаружение признаков преступления органами внутренних дел / В.Н. Григорьев. - Ташкент, 1986. $88 \mathrm{c}$.

16. Попов А.П. Непосредственное обнаружение признаков преступления как повод к возбуждению уголовного дела. Автореф. дис. ... канд. юрид. наук / А.П. Попов. - Н. Новгород, 1999. - 19 c.

17. Кальницкий В.В. Возбуждение уголовного дела в системе уголовно-процессуальной и оперативно-розыскной деятельности / В.В. Кальницкий, Ю.А. Николаев // Вопросы применения Федерального закона «Об оперативно-розыскной деятельности». - Омск:, 1998. - С. 29-32.

18.Земскова А.В. Правовые проблемы использования результатов оперативно - розыскных мероприятий в уголовно процессуальном доказывании / А.В.Земскова. - Волгоград, 2000. - C. 62-63. 
19.Гущин А.Н. Использование оперативно-розыскной информации в уголовно-процессуальном доказывании / А.Н. Гущин, Ю.В. Франциферов, Н.А. Громов // Российский следователь. - 2000. - № 4. - С. 15-17.

\section{Information about the author:} Sachko O. V.,

Candidate of Law, Associate Professor. Docent of the Department of Administrative and Criminal Law Oles Honchar Dnipro National University 72, Haharin av., Dnipro, Ukraine 